までの横方问が高い抵抗値を示している。すな わち方向によっては均質性がみられることがわ かる。

図 4 は溶解，吹付けられたグラスウールフィ ルタのマスクの流量・圧特性曲線である。各サ ンプル間の変動がはげしく方向性もない．この ように各サンプルの值が全体に高いのに，中に は例外的泜い值のものを含む。

\section{4. 考 察}

既報の測定回路を使って，市販の多種類の手 術用フェイスマスクについて流量・圧特性の分 布を検討した。 その分布は多様な傾向を示す が，時として銘柄，規格番号，ロット番号が同 一のマスクにおいても製品にむらがみられた。 このことはマスクの品質について検討する時, 大きな問題点である。マスクの特性として Air exchange pressure 学詳細汇調べるには，今回 私たちが行ったように多数力所からサンプルを 採取して調べる方法が，必要であると思われ る.今までのデータでは Air exchange pressure が均質と思われるマスクは一般に抵抗值
が高い，それに比べて均質性のないマスクは変 動がはげしく，全体に抵抗值は高いが例外的に 低い抵抗值のものも含まれている。

\section{5. 結 論}

1 枚のマスク上での Air exchange pressure の分布の傾向は次の 3 群に大別できる.

(1)同一マスク上での変動が少なく，材質が均 質と思われるもの。

(2)方向によっては均質性があると認的られる もの.

(3)変動が大きくどの方向にも均質性が認为ら れないもの.

\section{引用文献}

1）河井敏博, 實川传太郎他：手術用フェイマスク の通気性の測定法について (第 3 報): 䀢器学, 52, Suppl., 139-41, 1982

2) Sataro Jitsukawa et al. : An Autoregression Analyzing Method of the Flow-Pressure Characteristics of Surgical Face Masks: Medical Journal of Osaka University, 33, No 3-4, 1983

\title{
43. 手術用フェイスマスクの流量・圧特性の測定法
}

\section{につレて（第 5 報）}

\section{——サンプリング方法の検討——}

河井敏博*富田敏司*中谷博* 宮本徳廣* 中田精三* 森隆比古*

藤谷富男* 實川佐太郎* 米虫節夫*2

1.はじめに

1 枚のフェイスマスクの Air exchange pressure の分布（以後分布之略す）は，フェイス マスクの種類によりその分布が，(1)ほぼ均質な もの，(2)変動は大きいが方向性の認められるも の, (3)変動が大きくかつ万向性も認められない

* 大阪大学中央手術部

*2 近畿大学農学部農芸化学科
ものと 3 種に大別できることを本大会 演題 42

（以後演題 42 と略す）で報告した，われわれは さらに詳細に検討するためフェイスマスクの原 反に付いても分布を測定し，Military Specification M-36954 C (以後 Mil spec と略す) に 従った有効な 5 カ所のサンプリング方法を見出 だすため，統計的手法を用い検討してみた。

\section{2. 方 法}

測定装置は演題42で報告したとおうである。 
医器学 Vol. 54, Suppl. (1984)

約 7 inch 幅の原反 $A$ 社 2 種, $B$ 社 5 種 (以後 A-1，B-1 のように記号で区別する）の他, 代 表的な分布を示すフェイスマスクを測定対象と し，それぞれについて 5 行 5 列の 25 力所からの サンプルを取り以下の方法で検討した。

(1) Air exchange pressure の分布図

マイクロコンピュータ, NEC の PC-9801 F を使用しサンプル位置ごとに測定值の平均をと り，疑似的に 3 次元表示でプリントアウトし た，図中にサンプル位置を示す番号を付け，高 さは Air exchange pressure に対応させた。

(2) 3 元配置法に上る分散分析

原反での分布の傾向を調ぶるため長手方向の 変動を要因 $\mathrm{A}$, それと重直方向の変動を要因 $\mathrm{B}$, 繰り返しの変動を要因 $\mathrm{C}$, 平方和を $\mathrm{S}$, 自 由度を $\phi$, 分散を $\mathrm{V}$, 期待值を $\mathrm{E}(\mathrm{V})$, 分散比 を $\mathrm{F}$ とし， 3 元配置法により分散分析を行っ た. 分散比の検定は全て危険率 $5 \%$ で行った。

(3) A方向と B方向との分散の比較

分布の方向性の有無を簡単に調べるための近 似的な検定法として, 原反の要因 $\mathrm{A}$ と要因 $\mathrm{B} の$ 分散比を検討した。

(4) 斜め 5 カ所のサンプリング方法の検討

サンプル位置ごとの平均值を 2 元配置法で分 散分析した結果と斜め 5 力所, 2 万向の分析結 果とを比較検討した.

(5) フェイスマスクでの斜め 5 カ所のサンプ リング方法の検証

斜め 5 カ所のサンプリング方法の検討をフェ イスマスクで行った.

\section{3. 結 果}

(1) Air exchange pressure の分布図

図 1 は分布が縦縞を示した原反 B-1 の場合 で，サンプル \#3，\#8，\#13，\#18，\#23のみ が一段と高く山型であった。

(2) 3 元配置法による分散分析

分布がほぼ均質な場合は, 要因 $\mathrm{A}$ と要因 $\mathrm{B} の$ 分散が小さく, 分散比も小さな值を示した（表 略). 分布が縦縞を示した原反 B-1 の分散分析 表を表 1 亿示す, V B の值のみが他の分散より 極端に大きく分布の特色を示している.この傾 向は要因 A と要因 B との分散比 166.495 を求め ても概略は判断できる.

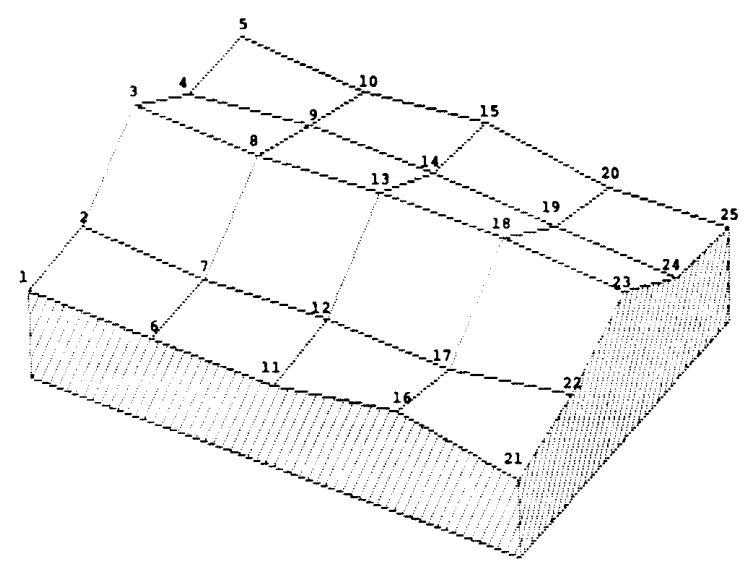

図 1 原反 B-1の Air exchange pressure の分布

表 1 原反 B-1の分散分析表 ( 3 元配置)

$$
\left(\begin{array}{l}
\mathrm{A}: \text { 長手方向の変動 } \\
\mathrm{B}: \text { 長手方向と垂直方向の変動 } \\
\mathrm{C}: \text { 繰り返しによる変動 }
\end{array}\right)
$$

\begin{tabular}{lcccc} 
& $S$ & $\Phi$ & $V$ & $E(V)$ \\
\hline$A$ & 0.43 & 4 & 0.107 & $\sigma \mathrm{e}^{2}+5 \sigma A \times C^{2}+30 \sigma A^{2}$ \\
B & 71.26 & 4 & 17.815 & $\sigma \mathrm{e}^{2}+5 \sigma B \times C^{2}+30 \sigma B^{2}$ \\
C & 0.03 & 5 & 0.006 & $\sigma \mathrm{e}^{2}+25 \sigma \mathrm{C}^{2}$ \\
$\mathrm{~A} \times \mathrm{B}$ & $\mathbf{5 . 2 0}$ & 16 & 0.325 & $\sigma \mathrm{e}^{2}+6 \sigma A \times B^{2}$ \\
$\mathrm{~A} \times \mathrm{C}$ & 0.09 & 20 & 0.004 & $\sigma \mathrm{e}^{2}+5 \sigma A \times C^{2}$ \\
$\mathrm{~B} \times \mathrm{C}$ & 0.10 & 20 & 0.005 & $\sigma \mathrm{e}^{2}+5 \sigma B \times C^{2}$ \\
$\mathrm{e}$ & 0.28 & 80 & 0.003 & $\sigma \mathrm{e}^{2}$ \\
\hline $\mathrm{T}$ & $\mathrm{77.39} 149$ & & \\
F $O=\frac{V B}{V A}=166.495$ & &
\end{tabular}

表 2 A方向とB方向との分散の比較 VA VB VB/VA

\begin{tabular}{rrrr} 
& \multicolumn{1}{c}{ VA } & \multicolumn{1}{c}{ VB/VA } \\
\hline $\mathrm{A}-1$ & 0.218 & 15.304 & 70.201 \\
$\mathrm{~A}-2$ & 0.238 & 0.285 & 1.197 \\
$\mathrm{~B}-1$ & 0.107 & 17.815 & 166.495 \\
$\mathrm{~B}-2$ & 1.029 & 10.979 & 10.669 \\
$\mathrm{~B}-3$ & 0.673 & 1.289 & 1.915 \\
$\mathrm{~B}-4$ & 0.419 & 4.189 & 9.997 \\
$\mathrm{~B}-5$ & 0.728 & 65.338 & 89.750 \\
\hline
\end{tabular}

(3) A方向と B方向との分散の比較

表 2 亿示すように原反 $\mathrm{A}-2$ と原反 $\mathrm{B}-3$ は分 散比が 1.197，1.915 と小さかった. しかしい ずれも要因 $\mathrm{B}$ の分散は要因 $\mathrm{A}$ の分散より大きな 値を示した。

フィルタ素材の米国特許製法の 1 つに, 溶け たフィルタ原料と熱風を回転ドラム上のカバー 
表 3 原反 B-1 の分散分析表（2 元配置）

$\mathrm{A}:$ 長手方向の変動

$B$ : 長手方向と垂直方向の変動

\begin{tabular}{|c|c|c|c|c|}
\hline & $s$ & $\Phi$ & V & $E(V)$ \\
\hline A & 0.07 & 4 & 0.017 & $\sigma \mathrm{e}^{2}+5 \sigma \mathrm{A}^{2}$ \\
\hline B & 11.87 & 4 & 2.967 & $\sigma \mathrm{e}^{2}+5 \sigma B^{2}$ \\
\hline e & 0.87 & 16 & 0.054 & $\sigma \mathrm{e}^{2}$ \\
\hline$T$ & 12.81 & 24 & & \\
\hline \multicolumn{5}{|c|}{$\bar{\sigma} B^{2}=\frac{V B-V E}{5}=0.682$} \\
\hline c.fl & 斜め5 & 針 5 西所のみのデータ & \multicolumn{2}{|c|}{ （右下がわ】） } \\
\hline c.f2 & & 㸯めธ百肵のみのデータ & \multicolumn{2}{|c|}{ (右上がりノ) } \\
\hline
\end{tabular}

ストックに吹付けて，連続的にフィルタ一素材 を作る製法がある（図略），長手方向と平行に 分散が小さいのは製法に起因していることを同 わせた。

(4) 斜め 5 力所のサンプリング方法の検討

(1) 表 3 に原反 B-1 の分散分析表を示す. 全 体の分散は要因 $\mathrm{A}$ のほうがきく，その期待 值 $\widehat{o} \mathrm{~B}^{2}$ は0.582 と斜めに取った方向の期待值 $0.727,0.797$ とよく致した.

(2) ほぼ均質な原反 A-2 についての分析結果 も，全体の分散の大きい方の期待值 $\hat{\sigma} \mathrm{B}^{2}$ は
表 4 方向性のあるフェイスマスクの分散分 析表 ( 2 元配置)

[A : Nosepiece と垂直方向の変動

B : Nosepiece と水平方向の変動

\begin{tabular}{rrrcc} 
& $S$ & $\Phi$ & $V$ & $E(V)$ \\
\hline$A$ & 2.25 & 4 & 0.562 & $\sigma \mathrm{e}^{2}+5 \sigma A^{2}$ \\
$B$ & 0.03 & 4 & 0.007 & $\sigma \mathrm{e}^{2}+5 \sigma B^{2}$ \\
$\mathrm{e}$ & 0.51 & 16 & 0.031 & $\sigma \mathrm{e}^{2}$ \\
\hline
\end{tabular}

$\sigma A^{2}=\frac{V A-V e}{5}=0.106$

c.f1 斜め5自所のみのデータ（右下がり ） $V=0.101 \quad(\Phi=4)$

c.f2 料め5苗原のみのデータ (右上がりノ) $V=0.175 \quad(\Phi=4)$

0.005 と斜めに取った 2 方向の期待值 0.015 , 0.029 とよく一致した（表略）.

(5)フェイスマスクでの斜め 5 カ所のサンプ リング法の検証

分布の縞が Nosepiece に平行になっている フエイスマスクでの分散分析表を表 4 に示す. この場合も分散の大きい方の期待值 $\hat{\sigma} \mathrm{A}^{2}$ は 0.106 と斜め 2 方向の期待值 $0.101 ， 0.175$ とよ く一致した.
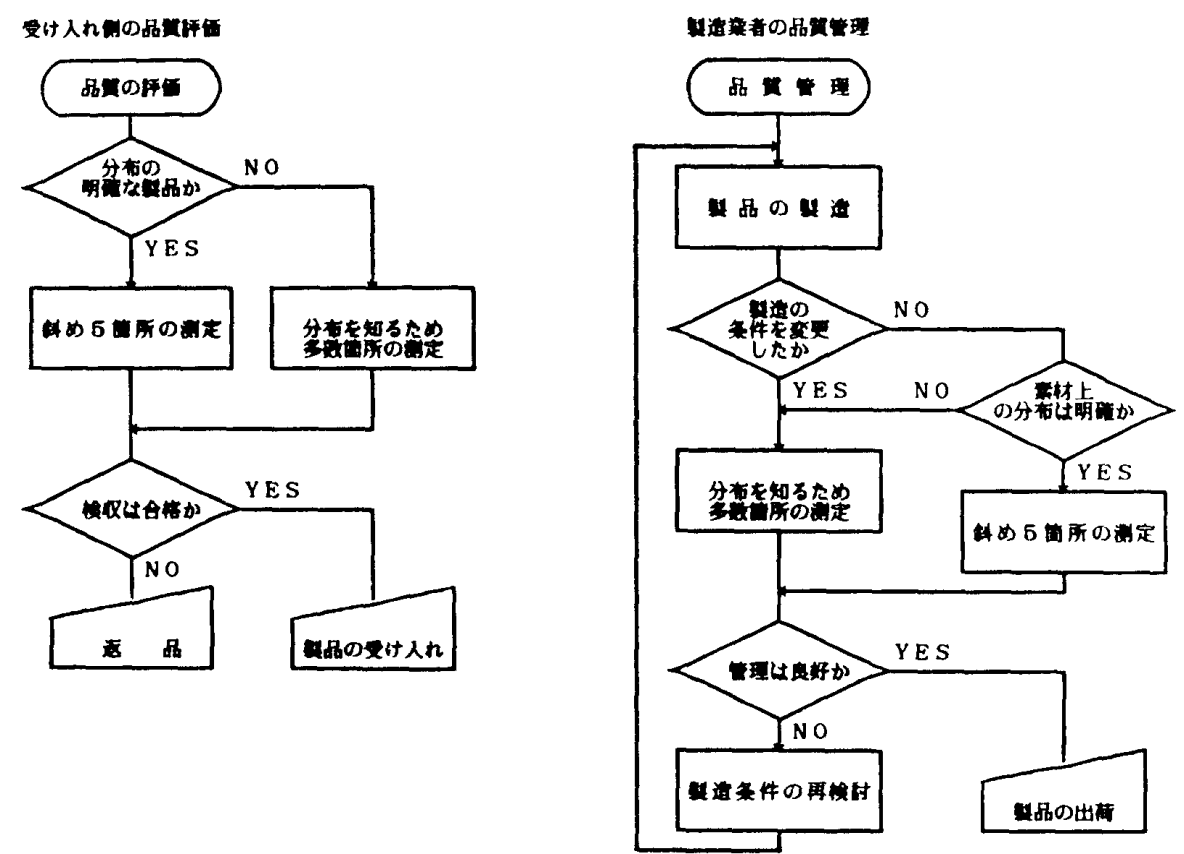

図 2 斜め 5 カ所のサンプリング法の応用 


\section{4. 考 察}

フェイスマスクでみられた分布の方向性は原 反に标いてもみられ，それがフィルタ素材の製 法に起因していることを伺わせた。われわれが 見出だした Mil spec に従った斜的に 5 カ所取 るサンプリング方法は, 縞の方向には関係なく 分散の大きい方表して晾り，分布がわかって いるものについては斜め 5 カ所のサンプリング だけで全体を評価できる有効なサンプリング方 法と考えられる。われわれのサンプリング方法 を製造メ一カの品質管理あるいは，ユーザの製 品受け入れ時の品質評俩に応用する例をフロー チャ一ト図 2 に示市. 図右の製造メ一力の場合 についてみると，製造条件を変更した場合には 分布を知るために，演題42で報告した方法等で
多数力所測定する必要があるが，製造条件は変 わらず素材上の分布が明確な場合は，斜め 5 力 所の測定だけで製造工程の管理が良好に行われ ているかどうかの評価が行える。また図左側の 製品の受け大れの場合は分布が明確な製品であ れば斜め 5 カ所のみの測定で品質評価が行える ことを示している.

\section{5. 結 論}

Military Specification M-36954 C に従った 有効な 5 カ所のサンプリング方法は，分布が明 磼な場合は斜めに 5 カ所サンプリングする方法 が有効である。しかし分布が明確でない場合は 演題42で報告した方法等で多数カ所測定する必 要がある.

\section{4. 電気メス 2 台同時使用の実態に関するアンケート調查報告}

日本医科器械学会学術部, 電気メ又規格調査 委員会を代表して報告する。本委員会愔従来種 々の使用上の問題点を指摘されている電気メス の使用について指針の検討を行い，1昨年度に その第 1 次案を本学会誌に揭載した。 その後, 電気入スの同時 2 台使用についての理論的解析 が，東大医用電子研究施設斎藤教授らを中心と して発表されると同時に，また奉際問題として も取り上げられ，この問題にも適切なガイドラ インをつくる必要が生じてきた。電気メス 2 台 同時使用は，心臟手術を中心にそのケースが増 大しつつあり，熱傷の危険性の増大， 2 台の電 気メスの高㓮波の相互干渉によるモード変化な どの可能性が考えられる，当委員会では，昨年 度作業として電気メス 2 台同時使用の実態につ

* 日本医科器伐学会電気入ス規格調查委員会委員 長

*2 日本医科器珹学会電気入ス規格調查委員会調查 委員
き全国規模アンケート調查を実施した。

調查対象は全国の一般病床数 400 床以上の主 要病院の中から約 100 病院抽出し, 手術部責 任者宛にアンケート内容を発送した。解答率は 64病院，約50\%であった。

手術室数と保有電気入ス台数との関係を示す と，ほぼ直線的な関係に市る（図 1 ）。

2 台同時使用の経験については, 使用したこ とがない施設が $49 \%$ ，ときどき使用するが 41 \%，以前使用したが現在使用しないが10\%であ り，また 2 台同時使用妾行った手術について は，心臓外科が圧倒的に多くて50\%, 脳神経外 科 $24 \%$, 一般外科 $15 \%$, 消化器外科 $9 \%$, 整形 外科 $3 \%$ であった。 2 台同時使用時の電気入ス 出力モ一ドの組み合わせは，凝固之凝固を組み 合わせた場合が多く $38 \%$ ，切開と切開（ブレン ドも含む） $30 \%$ ，切開と凝固が $22 \%$ ，その他 10 $\%$, 次に 2 台同時使用時の電気メスの種類の組 み合わせは, フローティング型とフローティン 